\title{
Correlates of Sleep-related Disorders, Dream-related Factors, and Nightmares in Acute Myocardial Infarction Patients: Severity of Coronary Artery Stenosis, Chest Pain, and Somatic Symptoms
}

\author{
Akut Miyokard Infarktüslü Hastalarda Uyku ile Ilgili Bozukluklar, Rüyayla Ilgili \\ Faktörler ve Kabusların Ilișkileri: Koroner Arter Stenozu, Göğüs Ağrısı ve Somatik \\ Semptomların Șiddeti
}

\author{
(1) Mostafa Bahremand *,****, (1) Marzieh Parvin**, (1) Saeid Komasi*** \\ *Imam Ali Hospital, Kermanshah University of Medical Sciences, Department of Cardiology, Kermanshah, Iran \\ **Kermanshah University of Medical Sciences, Department of Psychology, Kermanshah, Iran \\ ***Imam Reza Hospital, Kermanshah University of Medical Sciences, Clinical Research Development Center, Kermanshah, Iran \\ ****Student Research Committee, Kermanshah University of Medical Sciences, Kermanshah, Iran
}

\begin{abstract}
Objective: Sleep-related disorders and rapid eye movement-sleep parasomnias such as nightmares are among the threatening factors for the quality of life in clinical populations such as myocardial infarction (MI) patients. The present study was done to investigate the correlates of sleep-related disorders, dream-related factors, and nightmares in MI patients.

Materials and Methods: In this cross-sectional study, $222 \mathrm{Ml}$ patients admitted to a hospital in western Iran participated in the study during June-December 2018. Patients completed several standard tools related to sleep and dream. The stenosis severity and extent were assessed using angiography by an expert cardiologist. Data were analyzed using the Pearson correlation coefficient and multiple regression analysis.

Results: The mean ( \pm standard deviation) age of patients $(51.8 \%$ male) was $63.6 \pm 51.3$. The prevalence of poor sleep quality was $98.2 \%$. Somatic symptoms were strongest correlates of the poor sleep quality $(p<0.001)$, sleep self-efficacy $(p<0.001)$, nightmare frequency and severity $(p<0.001)$, and emotionally negative dream $(p=0.006)$. Chest pain and stenosis severity were unable to explain any of the sleep-related disorders or dream-related factors. Somatic symptoms $(p<0.001)$ and chest pain $(p=0.029)$ were lower in patients with fearful dream content compared to those without fearful content.

Conclusion: Compared to the stenosis severity or chest pain, somatic symptoms are the strongest correlates of sleep-related disorders and dream-related factors included sleep self-efficacy and emotionally negative dream along with nightmare frequency and severity. Although, the relationship between somatic symptoms and fearful dream content is a complex phenomenon. Future longitudinal studies with several follow-up stages can provide valuable findings.
\end{abstract}

Keywords: Artery stenosis, Chest pain, Dream, Myocardial infarction, Sleep disorders, Somatic symptoms
Öz

Amaç: Uyku ile ilişkili bozukluklar ve kabuslar gibi hızlı göz hareketiuyku parasomnileri, miyokard infarktüslü (Mi) hastalar gibi klinik popülasyonlarda yaşam kalitesi için tehdit edici faktörler arasındadır. Bu çalışma, Mi hastalarında uyku ile ilişkili bozukluklar, rüya ile ilgili faktörler ve kabusların ilişkilerini araştırmak için yapıldı.

Gereç ve Yöntem: Bu kesitsel çalışmada, İran'ın batısındaki bir hastaneye yatırılan 222 Ml hastası, Haziran-Aralık 2018 döneminde çalışmaya katıldı. Hastalar, uyku ve rüya ile ilgili birkaç standart aracı tamamladı. Stenozun şiddeti ve yaygınlığı, uzman bir kardiyolog tarafından anjiyografi kullanılarak değerlendirildi. Veriler, Pearson korelasyon katsayısı ve çoklu regresyon analizi kullanılarak analiz edildi. Bulgular: Hastaların (\%51,8 erkek) ortalama ( \pm standart sapma) yaşı $63,6 \pm 51,3$ yıl idi. Kötü uyku kalitesi prevalansı \%98,2 idi. Somatik semptomlar en güçlü olarak kötü uyku kalitesi $(p<0,001)$, uyku özyeterliği $(p<0,001)$, kabus sıklığı ve şiddeti $(p<0,001)$ ve duygusal olarak olumsuz rüya $(p=0,006)$ ile korelasyon gösterdi. Göğüs ağrısı ve stenozun şiddeti, uyku ile ilgili bozuklukları veya rüya ile ilgili faktörlerin hiçbirini açıklayamadı. Korkulu rüya içeriğine sahip hastalarda, korku içeriği olmayanlara göre somatik semptomlar $(p<0,001)$ ve göğüs ağrısı $(\mathrm{p}=0,029)$ daha azdı.

Sonuç: Stenoz şiddeti veya göğüs ağrısına kıyasla, somatik semptomlar en güçlü olarak uyku ile ilgili bozukluklar ve uyku özyeterliliği ve duygusal olarak olumsuz rüya ile birlikte kabus sıklı̆̆ı ve ciddiyetini içeren uyku ile ilişkili faktörler ile korelasyon gösterirler. Bununla birlikte, somatik semptomlar ile korkulu rüya içeriği arasındaki ilişki karmaşık bir fenomendir. Birkaç takip aşamasına sahip gelecekteki boylamsal çalışmalar değerli bulgular sağlayabilir.

Anahtar Kelimeler: Arter stenozu, Göğüs ağrısı, Rüya, Miyokard infarktüsü, Uyku bozuklukları, Somatik semptomlar

Address for Correspondence/Yazışma Adresi: Saeid Komasi MSc, Imam Reza Hospital, Kermanshah University of Medical Sciences, Clinical Research Development Center, Kermanshah, Iran Phone: +98 8334276299 E-mail: s_komasi63@yahoo.com ORCID-ID: orcid.org/0000-0002-0198-3710 Received/Geliş Tarihi: 23.04.2020 Accepted/Kabul Tarihi: 16.08.2020

${ }^{\circ}$ Copyright 2020 by Turkish Sleep Medicine Society / Journal of Turkish Sleep Medicine published by Galenos Publishing House. 


\section{Introduction}

Sleep, as one of the basic human behavior and the vital needs, has a serious impact on general health (1). Sleep function included energy conservation, preparing the body for daily activities, recovering energy for better focus, adaptability and adjustment, reduction in stress and neurological pressures, physical well-being (2). Sleep also provides the conditions for dreaming and emotion regulation (3). Sleep-related disorders and dream-related factors are the main facilitators for types of diseases and mortality that in turn can increase health costs in worldwide countries (4). The recent reports show that these disorders are seen in 0.4 to $48 \%$ of the USA population, and 8.8 to $59.2 \%$ of the Iranian population (1).

The sleep-related disorders and dream-related factors also are among the threatening factors for the quality of life in clinical populations such as patients with cardiovascular diseases (CVDs). Sleep disturbances significantly increase the risk of developing heart events such as myocardial infarction (MI) $(1,5)$. Conversely, these disorders such as poor sleep quality are common in 70 to $71.7 \%$ of MI patients $(2,6)$. Short sleep duration, poor sleep quality, and somatic symptoms are common consequences of heart events even 18 months after cardiac rehabilitation (7).

The dream also is one type of unique mental activity during sleep that may affect several functions included mood regulation, integration of new information with the available memory system, and adjustment (3). Although there is no consensus on what is called dream disorder, nightmares are one of the most important subsets (8). Nightmares are related to cardiac markers such as heart rate and irregular heartbeats $(9,10)$. Also, dream anxiety and related emotions are associated with the incidence of MI during sleep (11). Mutually, MI patients usually report great anxiety due to fetal risk or invasive therapeutic procedures, which in turn may be the trigger of emotionally negative dream related to threatening health disease (3). Previous studies refer to poor sleep quality, sleep disorders, and dreams with the emotionally negative load as outcomes of CVDs and $\mathrm{MI}(3,12-15)$. However, limited attention has previously been paid to the correlates of these disorders after MI. Researchers cited factors such as gender, age, body mass index, exercise, blood triglycerides, and lower levels of epinephrine, norepinephrine, and cortisol $(12,13,15)$. There has been little attention given to stenosis severity, the intensity of chest pain, and other somatic symptoms. Thus, the purpose of the present study was to investigate the correlates of sleeprelated disorders, dream-related factors, and nightmares in $\mathrm{MI}$ inpatients.

\section{Materials and Methods}

\section{Design and Context}

In this cross-sectional study, MI patients admitted at Imam Ali Hospital in Kermanshah, were invited to participate in the study from June to December 2018. Kermanshah is located in western Iran, and Imam Ali Hospital is a 214-bed special heart-clinic center located in the Kermanshah city.

\section{Participants and Sampling}

From June to December 2018, 239 MI patients admitted at the hospital were entered into the study using a consecutive sampling. The inclusion criteria for present sample were fluency in Farsi language; the age range of 18 to 90 years; education duration higher than five years; coronary artery stenosis confirmed using angiography by a cardiologist; and willingness to participate in the study. After an initial screening by the research team, only 222 had the inclusion criteria for the study or were willing to complete the inventories. Seventeen patients were excluded due to age higher than 90 years, poor education, and a lack of fluency in Farsi. Also, two people were excluded due to the unwillingness to participate in the study. Identified patients by the research team were entered into the study after providing written consent and obtaining the confidentiality of their identity. The ethical standards of this study were made according to the Helsinki Statement. Given the formula $(n>50+8 m)$ and three predictor variables in the main analysis, the minimum sample size should be more than 74 people for this study (16). This study was approved at the Ethics Committee of Kermanshah University of Medical Sciences (KUMS.REC.1394.202).

\section{Data Collection}

During the first week after the incidence of $\mathrm{Ml}$ and during admit in the hospital, the demographic and medical information of the patients such as gender, age, education level, sleeprelated disorders, dream-related factors, and nightmares was collected by an expert psychologist and the cardiologist. The questionnaires present to the patients in the hospital and they completed the tools carefully. Severity and extent of coronary artery stenosis assessed using conventional angiography by expert cardiologists. Instruments were included somatic symptoms assessed by The DSM-5 Level 2-Somatic Symptomadult measure, Brief Pain inventory (BPI), the Pittsburgh Sleep Quality index (PSQI), the Sleep Self-Efficacy questionnaire, the Disturbing Dreams and Nightmare Severity index (DDNSI), the Nightmare Frequency scale (NFS), the schredl's dream emotions manual, and the content analysis of dreams manual, which were present to each patient individually. After receiving the necessary explanations by the clinical psychologist, the patients completed the questionnaires.

\section{Research Instruments}

Brief Pain inventory: The BPI is a self-report instrument for determining the severity of pain. This tool categorizes the severity of pain on a 10 point scale measure. There zero indicates no pain and 10 is the indicator for a high level of pain (17). The reliability and validity of the tools in the Iranian population have been investigated and approved by Mirzamani et al. (18).

The DSM-5 Level 2-Somatic Symptom-Adult Measure: The instrument is an adaptation of the 15-item Patient health questionnaire physical symptoms. Each item the measure that assesses the domain of somatic symptoms is rated the severity of the somatic symptom during the past 7 days. Each question is rated on a scale of 0 to 2 ( 0 : not bothered at all; 1 : 
bothered a little; 2 : bothered a lot). The total score is between 0 and 30, with higher scores indicating greater severity of somatic symptoms. Levels of somatic symptom severity are characterized by four categories included minimal (0-4), low (5-9), medium (10-14), and high (15-30). The scale validity was confirmed by Kocalevent et al. (19).

Pittsburgh Sleep Quality index: The PSQI is a self-report questionnaire that was designed by Buysse et al. (20). This questionnaire included standard 18 items in which items are categorized under seven subscales. The subjective sleep quality (item 9), sleep latency (the mean of item 2 score and the score of part " $A$ " of item 5), sleep duration (item 4), habitual sleep efficiency (total score is calculated by dividing the total hours of sleep on the hours the person lies in bed, multiplied by 100), sleep disturbances (the mean of scores to Item 5), the use of sleeping medication (item 6), and daytime dysfunction (mean of scores of items $7 \& 8$ ). Each question is rated on a scale of 1 to 3 . These seven subscales comprise the total score of the questionnaire, ranging from 0 to 21 . The higher the total score indicates lower sleep quality. Scores higher than five indicate a fairly bad sleep quality. Cronbach's alpha of this questionnaire in an Iranian sample was reported 0.78 (21).

Sleep Self-Efficacy questionnaire: The questionnaire has nine items and each question is rated on a Likert scale of 1 to 5 , from completely unconfident (score 1) to completely confident (score 5). The sum of the scores of the questionnaire is between 9 and 45. Higher scores mean higher sleep self-efficacy (22). This questionnaire has acceptable reliability and validity and used in Iranian samples well (23).

Disturbing Dreams and Nightmare Severity index: The DDNSI is an expanded version of the validated NFQ designed by Krakow et al. (24). Because of difficulty in distinguishing bad dreams from disturbing dreams or nightmares, the DDNSI was designed to determine the presence of a clinically salient nightmare complaint. The questionnaire comprises five items on nights per week with nightmares, nightmare count per week, awakenings due to bad dreams, the severity of nightmare problem, and intensity of actual nightmares. Items are scored from 0 to 37 and a total score of 10 or higher indicated the presence of a clinically salient nightmare complaint. Krakow et al. (25) reported Cronbach's alpha for this scale equal to 0.83 . Nightmare Frequency scale: This scale that was developed by Stumbrys et al. (26) has eight items. The questions are included never, less than once a year, about once a year, about 2-4 times a year, about once a month, about 2-3 times a month, about once a week, and several times a week. The total score is rated on a scale of 0 to 7 . The re-test reliability with a fourweek interval for the scale was 0.75 . Also, the eight-point scale is a valid instrument for assessing individual differences in nightmare frequencies (26).

Schredl's Dream Emotions Manual: The instrument that developed by Schredl (27) investigates a dream with any positive or negative emotion. The severity of emotional content (both positive and negative emotions) is rated on a scale of 0 to 4 from none intense emotions. Schredl et al. (28) were reported inter-rater reliability for the scale equal to 0.82 for negative emotions and 0.64 for positive emotions. The tool has also been used well in Iranian heart patients $(3,29)$.

Content Analysis of Dreams Manual: The questionnaire was designed by Hall \& Van de Castle (30). The dream content categorized in five emotional dimensions included distress, anger, happiness, fear, and sadness. The type of experienced emotion in the dream selected between one and more of these five emotions. According to the previous reports, the exact agreements for the Hall and Van de Castle system vary between 61 and $98 \%$ (30). The validity of this instrument is suitable and acceptable (27). The tool has also been used well in a heart patients sample in Iran (3).

\section{Statistical Analysis}

The continuous variables were reported as mean and standard deviations (SD), and discontinuous data were reported as frequency and percentage. To compare the scores of chest pain, somatic symptoms, sleep-related disorders, dream-related factors, nightmares, stenosis severity and extent, and age between men and women chi-square and independent t-test were used. In the main analysis, the Pearson correlation coefficient used to assess the relationship between stenosis severity, chest pain, and somatic symptoms with sleep-related disorders, dream-related factors, and nightmares. Multiple linear regression analysis applied after investigating the nonviolation of the assumptions of regression analysis such as normality distribution (13). Six separated models of linear regression analyses applied to assess the explanation role of stenosis severity, chest pain, and somatic symptoms to predict (i) the sleep quality, (ii) sleep efficacy, (iii) nightmare frequency, (iv) nightmare severity, (v) emotionally negative dream, and (vi) emotionally positive dream. SPSS software version 20 (IBM Corp., Armonk, NY, USA) was used for data analysis. All statistical tests related to the parametric variables with normal distribution performed as two-tailed and statistical significance was defined as p-value $<0.05$.

\section{Results}

The mean ( \pm SD) age of patients (51.8\% male) was $63.6 \pm 51.3$. Ninety-eight and two-tenths percent of the patients were poor sleepers. Other data about physical problems, sleep-related disorders, dream-related factors, nightmares, and stenosis severity and extent are shown in Table 1. As can be seen, somatic symptoms were higher and sleep efficacy was lower among women than men. In other variables, there was no significant difference between men and women.

The results of Table 2 represent six models for the explanation of the sleep-related disorders, dream-related factors, and nightmares. As it seems, in all models, except for model $F$ (emotionally positive dreams), there is a significant correlation between somatic symptoms and the sleep-related disorders, dream-related factors, and nightmares $(p<0.001)$. Also, there is a significant correlation between the severity of chest pain and sleep-related disorders, dream-related factors, and nightmares in models $B$ to $E(p<0.05)$. However, the results of Table 2 showed that only somatic symptoms can significantly 
Bahremand et al.

Correlates of Sleep and Dream in AMI

\begin{tabular}{|c|c|c|c|c|}
\hline Variable & Total $(\mathrm{n}=\mathbf{2 2 2})$ & Female $(n=105)$ & Male $(n=117)$ & $\mathbf{p}$ \\
\hline Age $(M \pm S D)^{a}$ & $63.60 \pm 51.35$ & $68.62 \pm 62.94$ & $59.09 \pm 14.49$ & 0.168 \\
\hline \multicolumn{5}{|c|}{ Physical problems $(\mathrm{M} \pm \mathrm{SD})^{\mathrm{a}}$} \\
\hline Chest pain & $3.85 \pm 2.41$ & $3.85 \pm 2.39$ & $3.85 \pm 2.45$ & 0.995 \\
\hline Somatic symptoms & $11.16 \pm 5.54$ & $12.91 \pm 5.61$ & $9.58 \pm 4.99$ & 0.001 \\
\hline \multicolumn{5}{|c|}{ Sleep/dream factors $(\mathrm{M} \pm \mathrm{SD})^{\mathrm{a}}$} \\
\hline PSQI & $10.06 \pm 2.61$ & $10.20 \pm 2.75$ & $9.94 \pm 2.48$ & 0.460 \\
\hline Sleep efficacy & $26.78 \pm 6.41$ & $25.52 \pm 6.54$ & $27.96 \pm 6.07$ & 0.005 \\
\hline Nightmare frequency & $3.14 \pm 2.64$ & $3.27 \pm 2.71$ & $3.03 \pm 2.58$ & 0.517 \\
\hline DDNSI & $7.36 \pm 8.77$ & $8.09 \pm 8.82$ & $6.67 \pm 8.71$ & 0.232 \\
\hline Negative dream & $2.21 \pm 1.03$ & $2.19 \pm 1.07$ & $2.23 \pm 1.01$ & 0.778 \\
\hline Positive dream & $2.15 \pm 0.85$ & $2.05 \pm 0.85$ & $2.25 \pm 0.84$ & 0.082 \\
\hline Stenosis extent $(\%)^{\mathrm{b}}$ & & & & 0.482 \\
\hline One artery & $128(57.7)$ & $66(62.8)$ & $62(53.0)$ & \\
\hline Two arteries & $46(21.6)$ & $20(19.1)$ & $28(23.9)$ & \\
\hline Three arteries & $48(20.7)$ & $19(18.1)$ & $27(23.1)$ & \\
\hline Stenosis severity $(\%)^{\mathrm{b}}$ & & & & 0.205 \\
\hline Moderate & $69(31.1)$ & $37(35.2)$ & $32(27.4)$ & \\
\hline Sever & $153(68.9)$ & $68(64.8)$ & $85(72.6)$ & \\
\hline \multicolumn{5}{|l|}{ Dream content $(\%)^{b}$} \\
\hline Distress & $87(39.2)$ & $43(41.0)$ & $44(37.6)$ & 0.762 \\
\hline Anger & $10(4.5)$ & $5(4.8)$ & $5(4.3)$ & 0.905 \\
\hline Happiness & $58(26.1)$ & $22(21.0)$ & $36(30.8)$ & 0.069 \\
\hline Fear & $32(14.4)$ & $17(16.2)$ & $15(12.8)$ & 0.543 \\
\hline Sadness & $61(27.5)$ & $34(32.4)$ & $27(23.1)$ & 0.163 \\
\hline
\end{tabular}

explain the sleep-related disorders, dream-related factors, and nightmares, except for the emotionally positive dream. Models $A$ to $E$ respectively were able to explanation of $37.2 \%$ variance of sleep quality assessed by PSQI, 36.3\% variance of sleep efficacy, $28.6 \%$ variance of nightmare frequency, $34.9 \%$ variance of disturbing dreams and nightmare severity assessed by DDNSI, and $27.3 \%$ variance of the emotionally negative dream $(p<0.001)$. In model $F$, none of the variables could explain the emotionally positive dream $(p=0.855)$.

Table 3 shows the mean ( \pm SD) of chest pain and somatic symptoms along with frequency (\%) of stenosis severity in five types of dream contents included distress, anger, happiness, fear, and sadness. As can be seen, chest pain $(p=0.029)$ and somatic symptoms $(p<0.001)$ are lower in patients with fearful dream content compared to those without fearful dream content. Other variables did not differ between patients with types of dream content ( $p>0.05)$.

\section{Discussion}

The present study was done to investigate the correlates of sleeprelated disorders, dream-related factors, and nightmares in $\mathrm{MI}$ patients. Poor sleepers were $98.2 \%$ in the present study. The findings of the current study showed that somatic symptoms are the strongest correlate of sleep-related disorders, dreamrelated factors, and nightmares. Our results indicated that there is a significant relationship between somatic symptoms and poor sleep quality, sleep self-efficacy, emotionally negative dreams, and nightmare frequency and severity. MI as a sudden unexpected event usually causes severe fear and anxiety. These symptoms may affect sleep-related disorders and dreamrelated factors $(3,31)$. Somatic symptoms both directly and indirectly impair sleep quality. Firstly, these symptoms are mainly associated with pain in different areas of the body which can lead to insomnia and poor sleep quality $(32,33)$. The results of one study also showed that both somatic symptoms and pain after adjustment for age, sex, and depressive and anxiety symptoms relieve sleep disorders (34). Secondly, somatic symptoms can explain psychological distress in patients with CVDs (35). Psychological distress, in turn, leads to sleep disorders (36).

Another finding indicated that chest pain was unable to explain any of the sleep-related disorders, dream-related factors, and nightmares. Although, the results showed that there is a bivariate relationship between chest pain and sleep self-efficacy, nightmare frequency and severity, and negatively dream content. As mentioned above, pain and somatic symptoms 
Bahremand et al.

Correlates of Sleep and Dream in AMI

\begin{tabular}{|c|c|c|c|c|c|c|}
\hline Models & $r$ & $p$ & B & $\beta$ & $\mathrm{t}$ & $p$ \\
\hline Model A & \multicolumn{2}{|l|}{ PSQI } & & & & \\
\hline Chest pain & 0.090 & 0.092 & -0.039 & -0.036 & -0.531 & 0.596 \\
\hline Somatic symptoms & 0.370 & 0.001 & 0.182 & 0.384 & 5.636 & 0.001 \\
\hline Chest pain & -0.126 & 0.033 & -0.029 & -0.011 & -0.160 & 0.873 \\
\hline Somatic symptoms & -0.363 & 0.001 & -0.423 & -0.360 & -5.246 & 0.001 \\
\hline Model C & \multicolumn{2}{|c|}{ Nightmare frequency } & & & & \\
\hline Stenosis severity & 0.014 & 0.423 & 0.220 & 0.038 & 0.541 & 0.589 \\
\hline Chest pain & 0.171 & 0.008 & 0.089 & 0.082 & 1.102 & 0.272 \\
\hline Chest pain & 0.162 & 0.009 & 0.262 & 0.072 & 1.051 & 0.294 \\
\hline Somatic symptoms & 0.337 & 0.001 & 0.494 & 0.306 & 4.464 & 0.001 \\
\hline Model E & \multicolumn{2}{|c|}{ Emotionally negative dream } & & & & \\
\hline Stenosis severity & 0.013 & 0.425 & 0.045 & 0.020 & 0.297 & 0.767 \\
\hline Chest pain & 0.200 & 0.002 & 0.058 & 0.135 & 1.899 & 0.059 \\
\hline Somatic symptoms & 0.239 & 0.001 & 0.038 & 0.198 & 2.795 & 0.006 \\
\hline Model F & \multicolumn{2}{|c|}{ Emotionally positive dream } & & & & \\
\hline Stenosis severity & 0.051 & 0.228 & 0.103 & 0.056 & 0.798 & 0.426 \\
\hline Chest pain & 0.006 & 0.467 & -0.004 & -0.011 & -0.145 & 0.884 \\
\hline
\end{tabular}

in different areas of the body cause sleep disorders (32-34). However, chest pain alone could not explain the sleep-related disorders and dream-related factors well. This finding can be explained by the lack of control of confounding variables such as age or family support in the present study. On the other hand, chest pain caused by a MI is most acute, while chronic pain is more likely to cause sleep problems (37). In general, the mechanisms of pain and sleep-related problems are very complex. Genetic and environmental factors may play a role in the field (34), which requires much closer investigations.

Our results showed that there is no relationship between stenosis severity and sleep-related disorders, dream-related factors, and nightmares. Johansson et al. (38) founded that infarct size measured by conventional biochemical markers, left ventricle ejection fraction, and history of previous $\mathrm{Ml}$ are not related to the sleep disturbances. Mutually, other studies have suggested an association between sleep-related disorders, dream-related factors, and nightmares with cardiac markers and symptoms (8-10). Also, Ehrhardt et al. (39) refer to a complex interaction between sleep disorders such as sleep apnea and carotid stenosis.

Another finding unexpectedly indicated that chest pain and somatic symptoms are lower in patients with fearful dream content compared to those without fearful content. Probably those who experience fear emotion during sleep are less likely to exposure physical symptoms due to emotional regulation. Regulatory mechanisms dreaming and emotional salience in sleep mentation share similar neural substrates of those controlling emotions during wakefulness (40). Perhaps, bad dreams have an emotion regulator function (41). On the other hand, dreams must be remembered by patients; while they may be unable to recall some of the contents of the dream. This problem may lead to bias in the findings.

Although our findings may be useful to researchers and cardiovascular clinicians, lack of control of confounding variables such as age differences and family support of patients 
Bahremand et al.

Correlates of Sleep and Dream in AMI

\begin{tabular}{|c|c|c|c|c|}
\hline \multirow[t]{2}{*}{ Variable } & \multicolumn{2}{|c|}{ Stenosis severity ${ }^{a}$} & \multirow[t]{2}{*}{ Chest pain ${ }^{b}$} & \multirow[t]{2}{*}{ Somatic symptoms } \\
\hline & Moderate & Sever & & \\
\hline \multicolumn{5}{|l|}{ Distress } \\
\hline Yes & $22(31.9)$ & $65(42.5)$ & $3.88 \pm 2.42$ & $11.57 \pm 5.51$ \\
\hline no & $47(68.1)$ & $88(57.5)$ & $3.82 \pm 2.43$ & $10.88 \pm 5.47$ \\
\hline \multicolumn{5}{|l|}{ Anger } \\
\hline Yes & $1(1.4)$ & $9(5.9)$ & $3.88 \pm 2.42$ & $11.57 \pm 5.50$ \\
\hline No & $68(98.6)$ & $144(94.1)$ & $3.82 \pm 2.43$ & $10.88 \pm 5.47$ \\
\hline$P$-value & \multicolumn{2}{|l|}{0.146} & 0.851 & 0.359 \\
\hline \multicolumn{5}{|c|}{ Happiness } \\
\hline \multicolumn{5}{|l|}{ Fear } \\
\hline Yes & $10(14.5)$ & $22(14.4)$ & $3.24 \pm 2.25$ & $8.88 \pm 4.86$ \\
\hline No & $59(85.5)$ & $131(85.6)$ & $4.06 \pm 2.45$ & $11.99 \pm 5.47$ \\
\hline P-value & \multicolumn{2}{|l|}{0.945} & 0.029 & 0.001 \\
\hline \multicolumn{5}{|l|}{ Sadness } \\
\hline Yes & $17(24.6)$ & $44(28.8)$ & $4.33 \pm 2.83$ & $12.50 \pm 5.06$ \\
\hline No & $52(75.4)$ & $109(71.2)$ & $3.77 \pm 2.34$ & $10.92 \pm 5.53$ \\
\hline P-value & \multicolumn{2}{|l|}{0.568} & 0.235 & 0.134 \\
\hline
\end{tabular}

may lead to biased results. Also, the lack of access to sleeprelated problems histories and cross-sectional study design are other limitations. Future studies can provide valuable results by reviewing patients' sleep history and several follow-ups.

\section{Conclusion}

More than $98 \%$ of $\mathrm{MI}$ inpatients have poor sleep quality, which is mostly explained by somatic symptoms rather than the stenosis severity or chest pain. Somatic symptoms are also the strongest correlates of sleep-related disorders and dreamrelated factors included sleep self-efficacy, emotionally negative dream, and nightmare frequency and severity. Although, the relationship between somatic symptoms and fearful dream content is a complex phenomenon. Future longitudinal studies with several follow-up stages can provide valuable findings.

\section{Ethics}

Ethics Committee Approval: This study was approved at the Ethics Committee of Kermanshah University of Medical Sciences (KUMS.REC.1394.202).

Informed Consent: Consent form was filled out by all participants.

Peer-review: Internally peer-review.

\section{Authorship Contributions}

Surgical and Medical Practices: M.B., Concept: M.B., S.K., Data collection: M.P., Analysis: S.K., Search: S.K., Writing: M.B., S.K. Conflict of Interest: No conflict of interest was declared by the authors.

Financial Disclosure: Student Research Committee, Kermanshah University of Medical Sciences, Kermanshah, Iran (ID: 95139).

\section{References}

1. Khazaie $\mathrm{H}$, Komasi S. The importance of screening sleep disorders in outpatient cardiac rehabilitation programs in Iran. ARYA Atheroscler 2018;14:145-6.

2. Sasmita R, Thenmozhi P. Assess the quality of sleep among patient with myocardial infarction. Int J Applied Res 2019;5:213-6.

3. Komasi S, Soroush A, Khazaie H, Zakiei A, Saeidi M. Dreams content and emotional load in cardiac rehabilitation patients and their relation to anxiety and depression. Ann Card Anaesth 2018;21:388-92.

4. Benjamin EJ, Muntner $\mathrm{P}$, Alonso A, Bittencourt MS, Callaway CW, Carson AP, Chamberlain AM, Chang AR, Cheng S, Das SR, Delling FN, Djousse L, Elkind MSV, Ferguson JF, Fornage M, Jordan LC, Khan SS, Kissela BM, Knutson KL, Kwan TW, Lackland DT, Lewis TT, Lichtman $\mathrm{JH}$, Longenecker $\mathrm{CT}$, Loop MS, Lutsey $\mathrm{PL}$, Martin SS, Matsushita K, Moran AE, Mussolino ME, O'Flaherty M, Pandey A, Perak AM, Rosamond WD, Roth GA, Sampson UKA, Satou GM, Schroeder EB, Shah SH, Spartano NL, Stokes A, Tirschwell DL, Tsao CW, Turakhia 
MP, VanWagner LB, Wilkins JT, Wong SS, Virani SS; American Heart Association Council on Epidemiology and Prevention Statistics Committee and Stroke Statistics Subcommittee. Heart disease and stroke statistics-2019 update: a report from the American Heart Association. Circulation 2019;139:56-528.

5. Daghlas I, Dashti HS, Lane J, Aragam KG, Rutter MK, Saxena R, Vetter C. Sleep duration and myocardial infarction. J Am Coll Cardiol 2019;74:1304-14.

6. Silva Andrechuk CR, Ceolim MF. Sleep quality in patients with acute myocardial infarction. Texto Contexto Enferm Florianópolis 2015;24:1104-11.

7. Saeidi M, Rezaeeyan H, Bagherirad D, Saeidi M, Sharyatmadari M, Amani N, Komasi S. Mental consequences and behavioral health 18 month after outpatient cardiac rehabilitation in three separated profiles at baseline. Clin Epidemiol Global Health 2020;8:295-300.

8. Eiser AS. Dream disorders and treatment. Curr Treat Options Neurol 2007;9:317-24.

9. Tanev KS, Orr SP, Pace-Schott EF, Griffin M, Pitman RK, Resick PA. Positive association between nightmares and heart rate response to loud tones: relationship to parasympathetic dysfunction in PTSD nightmares. J Nerv Ment Dis 2017;205:308-12.

10. Asplund R. Nightmares, sleep and cardiac symptoms in the elderly. Neth J Med 2003;61:257-61.

11. elvi Y, Aydin A, Gumrukcuoglu HA, Gulec M, Besiroglu L, Ozdemir PG, Kilic S. Dream anxiety is an emotional trigger for acute myocardial infarction. Psychosomatics 2011;52:544-9.

12. de Batlle J, Turino C, Sánchez-de-la-Torre A, Abad J, Duran-Cantolla J, McEvoy RD, Antic NA, Mediano O, Cabriada V, Masdeu MJ, Teran J, Valls J, Barbé F, Sánchez-de-la-Torre M; Spanish Sleep Group. Predictors of obstructive sleep apnoea in patients admitted for acute coronary syndrome. Eur Respir J 2017;49:1600550.

13. von Känel R, Princip M, Schmid JP, Barth J, Znoj H, Schnyder U, MeisterLangraf RE. Association of sleep problems with neuroendocrine hormones and coagulation factors in patients with acute myocardial infarction. BMC Cardiovascr Disord 2018;18:213.

14. Reshetnik A, Puppe S, Bonnemeier H. Central Sleep Apnoe and Arrhythmogenesis after myocardial infarction-the CESAAR Study. Front Cardiovasc Med 2019;6:108.

15. Almamari RSS, Muliira JK, Lazarus ER. Self-reported sleep quality and depression in post myocardial infarction patients attending cardiology outpatient clinics in Oman. Int J Nurs Sci 2019;6:371-7.

16. Pallant J. SPSS survival manual: A step by step guide to data analysis using SPSS for Windows (Version 12). 2nd edn. Australia: Allen \& Unwin. 2005;142-52.

17. Bahremand M, Moradi G, Saeidi M, Mohammadi S, Komasi S. Reducing irrational beliefs and pain severity in patients suffering from non-cardiac chest pain (NCCP): A comparison of relaxation training and metaphor therapy. Korean J Pain 2015;28:88-95.

18. Mirzamani SM, Sadidi A, Salimi SH, Besharat MA. Validation of the Persian version of the Brief Pain Inventory. Acta Medica Iranica 2005;43:425-8.

19. Kocalevent RD, Hinz A, Brähler E. Standardization of a screening instrument (PHQ-15) for somatization syndromes in the general population. BMC Psychiatry 2013;13:91.

20. Buysse DJ, Reynolds CF 3rd, Monk TH, Berman SR, Kupfer DJ. The Pitsburgh Slep Quality Index: a new instrument for psychiatric practice and research. Psychiatry Res 1989;28:193-213.

21. Khazaie H, Zakiei A, Rezaei M, Hoseini SM, Alikhani M. Emotional dysregulation leads to reduced sleep quality when the level of repetitive negative thoughts is high: findings of a structural equation model. Iran J Psychiatry Behav Sci 2019;13:e64661.
22. Schlarb AA, Kulessa D, Gulewitsch MD. Slep characteristics, slep problems, and asociations of self-eficacy among German university students. Nat Sci Slep 2012;4:1-7.

23. Ranjbaran S, Dehdari T, Mahmoodi Majdabadi M, SadeghniiatHaghighi K. The survey of sleep self-efficacy and perceived social support status in patients with poor sleep quality after coronary artery bypass surgery. Razi J Med Sci 2014;21:33-42.

24. Krakow B, Schrader R, Tandberg D, Hollifield M, Koss MP, Yau CL, Cheng DT. Nightmare frequency in sexual assault survivors with PTSD. J Anxiety Disord 2002;16:175-90.

25. Krakow BJ, Melendrez DC, Johnston LG, Clark JO, Santana EM, Warner TD, Hollifield MA, Schrader R, Sisley BN, Lee SA. Sleep Dynamic Therapy for Cerro Grande Fire evacuees with posttraumatic stress symptoms: a preliminary report. J Clin Psychiatry 2002;63:673-84.

26. Stumbrys T, Erlacher D, Schredl M. Reliability and stability of lucid dream and nightmare frequency scales. Int J Dream Res 2013;6:123-6.

27. Schredl M. Characteristics and contents of dreams. Int Rev Neurobiol 2010;92:135-54.

28. Schredl M, Burchert N, Gabatin Y. The effect of training on inter rater reliability in dream content analysis. Sleep Hypnosis 2004;6:139-44.

29. Saeidi M, Soroush A, Golafroozi P, Zakiei A, Faridmarandi B, Komasi S. Risk factors and psychosocial correlates of emotionally negative dreams in patients referred to a cardiac rehabilitation center. Malaysian J Med Sci 2020;27:97-105.

30. Hall C, Van de Castle R. The content analysis of dreams. New York, NY: Appleton-Century Crofts; 1966.

31. Oh CM, Kim HY, Na HK, Cho KH, Chu MK. The effect of anxiety and depression on sleep quality of individuals with high risk for insomnia: A population-based study. Front Neurol 2019;10:849.

32. Tang NK. Insomnia co-occurring with chronic pain: Clinical features, interaction, assessments and possible interventions. Rev Pain 2008;2:2-7.

33. Roizenblatt M, Rosa Neto NS, Tufik S, Roizenblatt S. Pain-related diseases and sleep disorders. Braz J Med Biol Res 2012;45:792-8.

34. Zhang J, Lam SP, Li SX, Tang NL, Yu MW, Li AM, Wing YK. Insomnia, sleep quality, pain, and somatic symptoms: sex differences and shared genetic components. Pain 2012;153:666-73.

35. Redeker NS. Somatic symptoms explain differences in psychological distress in heart failure patients vs. a comparison group. Progr Cardiovasc Nurs 2006;21:182-9.

36. Cunningham TJ, Wheaton AG, Giles WH. The association between psychological distress and self-reported sleep duration in a populationbased sample of women and men. Sleep Disord 2015;2015:172064.

37. Chen Q, Hayman LL, Shmerling RH, Bean JF, Leveille SG. Characteristics of chronic pain associated with sleep difficulty in the older population: The MOBILIZE Boston Study. J Am Geriatr Soc 2011;59:1385-92.

38. Johansson I, Karlson BW, Grankvist G, Brink E. Disturbed sleep, fatigue, anxiety and depression in myocardial infarction patients. Eur J Cardiovasc Nurs 2010;9:175-80.

39. Ehrhardt J, Schwab M, Finn S, Guenther A, Schultze T, Witte OW, Rupprecht S. Sleep apnea and asymptomatic carotid stenosis: A complex interaction. Chest 2015;147:1029-36.

40. Scarpelli S, Bartolacci C, D’Atri A, Gorgoni M, De Gennaro L. The functional role of dreaming in emotional processes. Front Psychol 2019;10:459.

41. Tousignant $\mathrm{OH}$, Glass DJ, Fireman GD. Emotion regulation function of bad dreams and nightmares. Sleep 2018;41:347. 